\title{
Advanced Information Services for Cognitive Behaviour of Travellers
}

\author{
CSISZÁR, Csaba \\ Budapest University of Technology and Economics (BME) \\ Faculty of Transportation Engineering and Vehicle \\ Engineering (KJK) \\ Department of Transport Technology and Economics \\ (KUKG) \\ Budapest, Hungary \\ e-mail: csiszar.csaba@mail.bme.hu,
}

\author{
FÖLDES, Dávid \\ Budapest University of Technology and Economics (BME) \\ Faculty of Transportation Engineering and Vehicle \\ Engineering (KJK) \\ Department of Transport Technology and Economics \\ (KUKG) \\ Budapest, Hungary \\ e-mail: davidfoldes91@gmail.com
}

\begin{abstract}
Smart transportation is essentially leveraged by decision making of humans, especially behaviour of travellers. The behaviour (movements; information management) and the advanced information services are mutually entangled. The travellers and the ICT (integrated infocommunication systems of transportation) is considered as an undecomposable set, which has new cognitive capabilities. These capabilities are to be used for mobility related decisions in order to improve sustainability of transportation.

In order to reveal, how these capabilities coelvolve with smart transportation comprehensive system and process-oriented scientific research had been launched. Herewith the basic definitions, the architecture and the operation of the integrated system of smart transportation and the model of the smart traveller have been presented following top-down approach of system engineering.
\end{abstract}

Keywords-cognitive capabilities, information services, integration, mobile application, mobility management

\section{INTRODUCTION}

We have defined the concept of Cognitive Transport Informatics based on [1]: "multidisciplinary study of cognition and information science, which investigates human information processing mechanisms and processes and their application fields in transportation engineering". It aims at creation of integrated artificially cognitive systems, which not only communicate with the humans (e.g. travellers) but new capabilities can be attained to augmenting the human existing capabilities with entanglement of natural and artificially cognitive components. In this field recently study of travellers' behaviour has an increasing importance.

The research results has been derived from a wider approach, starting from the smart city as a framework. Smart city can be defined briefly as system of systems. In details: system where particular subsystems use the common resources in a synergic way in order to improve citizens' life quality, that is highly individual. One subsystem is transportation and one resource is information.
Recently there is a shift in the perception of transportation from the 'Intelligent transportation' to 'Smart transportation' [2]. It means in CogInfoCom approach that the advanced infocommunication technology is not simply applied in transportation for certain aims (enhanced safety and mobility, reduced environmental impact), but we should on one hand set aims in a wider context (quality of life, sustainability, accessibility) and on the other hand reveal new inner processes and capabilities focusing on humans. This can be achieved only through multidisciplinary approach and accessing to telecommunication network with higher speed and reliability.

The 'smartness' of a smart city component (e.g. transportation system, street, stop, traveller) can be assessed from the next perspectives:

- cognitive (data acquireing, processing) capabilities,

- ability of adaptivity to ever changing expectations and situations,

- value of information used for decisions.

Smart transportation is to be defined as follows: a transportation system operated by dynamic (real-time) data, which includes the human knowledge, intelligence and mechanism of decision-making in order to decrease/replace the human activities. The data are originated from a set of connected environmental as well as traffic sensors in order to understand the actual situations. Shortly: cooperative applications of advanced infocommunication technologies by transport infrastructure, in vehicles and by travellers.

Transportation as system and process is result of different decision types of society, transportation operators and travellers (citizens). In this CogInfoCom system the following human components types can be distinguished: dispatcher [3], [4], driver of public vehicle, traveller as driver [5], [6], [7], traveller as passenger and/or pedestrian [8], [9], [10]. Each human component type makes decisions, but the degree of regulation regarding the decision making is different. 
We have focused on the travellers, as their behaviour influence the mobility demands. The demands and supply are higly related, changes both in the attributes of the travellers and the transportation system have to be forecasted. Both planning and operation of transportation require investigation and modeling of travellers' complex behavior, which has two interacting primal components:

- information management (e.g. decisions),

- movements.

One important attribute of movements, the reason why this is done, i.e. participation in activities. The traveller is on one hand the source and on the other hand the user of the information services. With the 'intervention' a so called soft control loop can be realized.

Smart traveller can be defined as traveller using advanced information services (mostly by smart phone) before, during or after travelling in order to find the most appropriate (optimum) travel options. The smart traveller term covers pedestrian, biker, passenger and driver, laying emphasis on multimodal journey chains. The required cognitive capabilities depend on the current role of the traveller.

This topic is relevant, because resources for hard transportation infrastructure developments are rather limited, but potentials for improvement of cognitive processes are unstinted. Especially there are opportunities for proactive management, where forecast of future situations and consequences of decisions is possible. The objectives of the research were:

- determination of the 'background' ICT system (architecture, operation, data, functions/ information services) and their connections to the travellers,

- revealing cognitive capabilities of the humanmachine entity.

In the cognitive researches the goal is to facilitate evolving cognitive processes with infocommunication devices so that the capabilities of the human brain may not only be extended through these devices, irrespective of geographical distance, but may also interact with the capabilities of any artificially cognitive system [1].

We focused on information management during the literature review being kept in mind the operational and technological development [11] aspects. Kramers [12] explored functionality that can be included in a multimodal traveller information system to support sustainability-oriented decisions. It has been assessed that travel patterns and also transportation choices are modified during the trip by providing information for the users. Passengers' personal expectations and decision processes, as well as the impact of predicted information on a travellers' habit have been also surveyed and described by Jou et al. [13].

The users' trajectory analysis plays significant role to determine their demands and gain behaviour data. Different trajectory data types and their difficulties (data privacy, share, bias and modelling) are collected by Yue et al. [14]. Several studies [15], [16] described passive information collection technologies without active passenger collaboration using smartphones (e.g. location data using GPS, or cellular, Bluetooth, WiFi, etc. networks). Trajectory research based on smart phones and utilization of mobiles' data in smart cities were examined by Steenbruggen et al. [17]. Another technological way of collecting users' travel data is smart card. In this regard the data processing and data mining modes have been examined [14], [18].

\section{MODEL OF SMART TRANSPORTATION SYSTEM}

We have identified the following component types in the model of smart transportation system [19], [20]:

- information management functions (information services),

- $\quad$ information managing subsystems (including human and/or machine elements),

- data groups.

The information management functions have been categorized by application fields. Table I. summarizes the function groups and the associated information managing subsystems. Table II. unfolds the functions which affect the smart traveller using public transportation. Cognitive functions are indicated with bold letters. A new cognitive capability is 'learning' the user profile and habits, meanwhile "communication intensive" solutions with customer experience in focus are preferred.

TABLE I. FUNCTION GROUPS AND SUBSYSTEMS

\begin{tabular}{|c|c|c|c|}
\hline \multicolumn{2}{|r|}{ Function groups } & \multicolumn{2}{|r|}{ Subsystems } \\
\hline $\mathrm{F}_{1}$ & Smart Traveller Functions & $\mathrm{S}_{1}$ & $\begin{array}{c}\text { Smart Traveller } \\
\text { (interactive personal } \\
\text { mobile device) }\end{array}$ \\
\hline $\mathrm{F}_{2}$ & Intelligent Infrastructure Functions & $\mathrm{S}_{2}$ & $\begin{array}{c}\text { Intelligent } \\
\text { Infrastructure }\end{array}$ \\
\hline $\mathrm{F}_{3}$ & Intelligent Vehicle (+Driver) Functions & $\mathrm{S}_{3}$ & Intelligent Vehicle \\
\hline $\mathrm{F}_{4}$ & Public Transportation Management & $\mathrm{S}_{4}$ & $\begin{array}{c}\text { Public Transportation } \\
\text { Management Centre }\end{array}$ \\
\hline $\mathrm{F}_{5}$ & Traffic Flows'Management & \multirow{4}{*}{$\mathrm{S}_{5}$} & \multirow{4}{*}{$\begin{array}{c}\text { Transportation } \\
\text { Management Centre }\end{array}$} \\
\hline $\mathrm{F}_{6}$ & Parking Management & & \\
\hline $\mathrm{F}_{7}$ & (Automated) Fare Collection & & \\
\hline $\mathrm{F}_{8}$ & Monitoring, Control and Enforcement & & \\
\hline
\end{tabular}

The subsystems and their relationships/interactions are summarized in the general model (Figure 1). The subsystems may communicate either through the transportation management centres (indirectly) or by short-range communication (directly). The intelligent vehicles are equipped by on-board units (OBU) and require intensive data acquisition from the sensors. The intelligent travellers use personal devices (so called nomadic devices). 


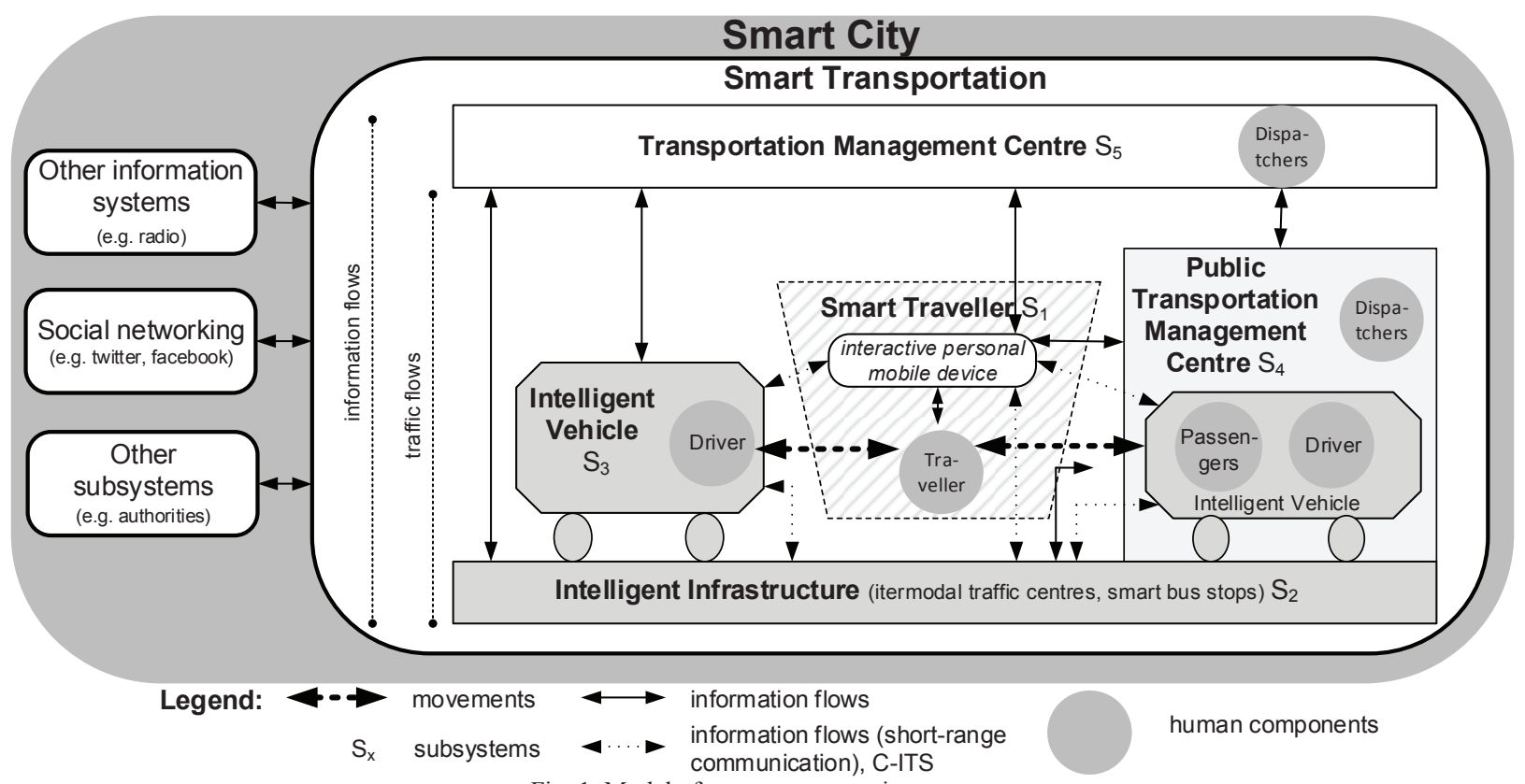

Fig. 1. Model of smart transportation system

TABLE II. INFORMATION MANAGEMENT FUNCTIONS AFFECTING THE SMART TRAVELLER USING PUBLIC TRANSPORTATION

\begin{tabular}{|c|c|c|}
\hline & & Functions \\
\hline \multirow{8}{*}{$\mathrm{F}_{1}$} & $F_{1,1}$ & Management of travellers' characteristics/user profile/account \\
\hline & $\mathrm{F}_{1,2}$ & Real-time traffic and travel information (alerts) \\
\hline & $\mathrm{F}_{1,3}$ & Personalized multimodal door-to-door predictive routing \\
\hline & $\mathrm{F}_{1,4}$ & Location and event based services, navigation (in- and out-door) \\
\hline & $\mathrm{F}_{1,5}$ & Weather and environmental information \\
\hline & $\mathrm{F}_{1,6}$ & Tourist information (accomodation booking) \\
\hline & $\mathrm{F}_{1,7}$ & $\begin{array}{c}\text { Traveller's feedback; (active, passive) crowd sourcing, } \\
\text { traveller's tracking }\end{array}$ \\
\hline & $\mathrm{F}_{1,8}$ & Emergency signal/calling/alert \\
\hline \multirow{4}{*}{$\mathrm{F}_{4}$} & $F_{4,1}$ & Management of seat reservation (check-in) \\
\hline & $\mathrm{F}_{4,2}$ & Demand responsive transportation management (taxi) \\
\hline & $\mathrm{F}_{4,3}$ & Management of driver service \\
\hline & $\mathrm{F}_{4,4}$ & $\begin{array}{c}\text { Management of shared mobility } \\
\text { (car and bike sharing, rental, car-pooling) }\end{array}$ \\
\hline \multirow{3}{*}{$\mathrm{F}_{6}$} & $F_{6,1}$ & Park\&ride information (static/dynamic) \\
\hline & $\mathrm{F}_{6,2}$ & Parking booking, management - dynamic pricing \\
\hline & $\mathrm{F}_{6,3}$ & Management of park-sharing \\
\hline \multirow{3}{*}{$\mathrm{F}_{7}$} & $\mathrm{~F}_{7,1}$ & Toll collection (usage-based, various rate schemes)) \\
\hline & $\mathrm{F}_{7,2}$ & Parking fee collection \\
\hline & $\mathrm{F}_{7,3}$ & Public transport fee collection (e-ticketing) \\
\hline
\end{tabular}

Function groups $\mathrm{F}_{5}-\mathrm{F}_{8}$ are realized predominantly either in or by cooperation of the transportation management centre $\left(\mathrm{S}_{5}\right)$, which is connected to all the other subsystems $\left(\mathrm{S}_{1}, \mathrm{~S}_{2}, \mathrm{~S}_{3}\right.$ and $\mathrm{S}_{4}$ ). This subsystem plays especially important role in regard of collaboration of transportation and other subsystems in the smart city. Functions in the group $F_{6}$ are performed partly as intelligent infrastructure functions but the strategic decisions, the optimization and the personal advices increasingly require the comprehensive operation of the transportation management centre, especially in network-wide context. The resource-efficient management of the transportation (network, services) requires integrated automated fare collection technologies $\left(\mathrm{F}_{7}\right)$.
In the future the direct communication of personal (nomadic) mobile devices plays an increasing role, especially in emergency situations and up-to-date traffic notifications. Some data, which are important for the traveller, but related indirectly to the transportation are stored not in the transportation management centre. Increases in numbers and types of sensors make possible collection of big amount of data with low frequency. The basic challenge: how is it possible to utilize these valuable data for improvement of processes?

Beside the mobile devices several other information sources are used in order to acquire the users' digital footprints. Based on the pictures of the CCTV the ,,world" is cognizable without being in the spot. We can draw conclusions from the attributes of the movements (e.g. speed, acceleration), from the purchase habits (analysis of the credit card usage). Smart cards can be used also in certain cases (or rather smart phone with NFC technology). Social networking (e.g. tweets, facebook messages and notifications) or other information portals (e.g. news on internet, radio or TV) can be also information sources. Using these modes we can make such statements and draw such conclusions, which we were not able to do before with the less advanced ICT technologies.

The cognitive capability of the entire system is laid in the possession of huge amount of data by transportation management centre $\left(\mathrm{S}_{5}\right)$. Data are originating from different sources and with different value but map the same entities or processes. Value of information depends on:

- probability of occurrence of a 'mapped' event,

- reliability,

- number of data sources of the same information, 
- context (available complementary information),

- aggregation/degree of processing.

In the next phase we have focused on the smart traveller presenting the decision making processes and disposing the traveller in the CogInfoCom system.

\section{SMART TRAVELLER}

The traveller is an agent, which operates in a multi-agent environment. Through communication to other agents, negotiation and game theoretical principles (decisions and sharing of resources), the CogInfoCom system (smart transportation) has the potential to obtain the optimal behaviour and/or the desired state. The travellers as agents do not simply act in response to their environment, they are able to exhibit goal-directed behavior. The humans can integrate experiences from various sensory channels and dissolve eventuell contradictions.

The impact of timeliness of the decision-making is summarized in Table III. Decisions are influenced by spatiality (e.g. modification of destination, route-choice), timeliness (e.g. postponement of journey) of travelling, choice of vehicle, etc. These complex processes depend also on static and dynamic features of the individuals and the transportation system [21]. Efficiency of transportation is basically influenced by travellers' reactions to the effects caused by the information system.

\section{TABLE III. TYPES OF DECISIONS REGARDING MOBILITY}

\begin{tabular}{|c|c|c|}
\hline Name & Description & $\begin{array}{c}\text { Influence mode of } \\
\text { decisions }\end{array}$ \\
\hline $\begin{array}{l}\text { awareness } \\
\text { building }\end{array}$ & $\begin{array}{c}\text { motivation for use of } \\
\text { sustainable transport modes } \\
\text { in a significant rate; } \\
\text { familiarization with } \\
\text { advantages of „soft”, } \\
\text { environmentally friendly and } \\
\text { public transport modes }\end{array}$ & $\begin{array}{c}\text { education, organization } \\
\text { of events }\end{array}$ \\
\hline $\begin{array}{l}\text { decisions } \\
\text { with long } \\
\text { term impacts }\end{array}$ & $\begin{array}{c}\text { residence-choice, workplace- } \\
\text { choice (distance work), } \\
\text { ownership of personal } \\
\text { vehicle, etc. }\end{array}$ & $\begin{array}{c}\text { mobility } \\
\text { advisors/coordinators, } \\
\text { Workplace Travel Plan, } \\
\text { motivation for car- } \\
\text { pooling } \\
\end{array}$ \\
\hline $\begin{array}{l}\text { decisions } \\
\text { with medium } \\
\text { term impacts }\end{array}$ & $\begin{array}{l}\text { membership for car-sharing } \\
\text { and bike-sharing, purchase of } \\
\text { monthly pass for public } \\
\text { transport, etc. }\end{array}$ & $\begin{array}{c}\text { public information } \\
\text { about transport services } \\
\text { in collective way, based } \\
\text { on static data }\end{array}$ \\
\hline $\begin{array}{l}\text { decisions } \\
\text { with short } \\
\text { term impacts }\end{array}$ & $\begin{array}{l}\text { location-choice for a certain } \\
\text { activity, route-choice, } \\
\text { vehicle-choice, determination } \\
\text { of time (time interval), } \\
\text { luggage conveyance, etc. }\end{array}$ & $\begin{array}{l}\text { personalized } \\
\text { information (influence) } \\
\text { regarding the certain } \\
\text { travelling based on up- } \\
\text { to-date data }\end{array}$ \\
\hline $\begin{array}{l}\text { decisions } \\
\text { with } \\
\text { momentary } \\
\text { impacts }\end{array}$ & $\begin{array}{l}\text { door selection for boarding } \\
\text { and alighting, use of } \\
\text { escalators, elevators, etc. }\end{array}$ & $\begin{array}{l}\text { public information on } \\
\text { board of vehicle and at } \\
\text { stations (stops) in } \\
\text { collective way, based } \\
\text { also on dynamic data }\end{array}$ \\
\hline
\end{tabular}

The interactive personal mobile device and travellers' ideal application was chosen to illustrate the relationships between functions and subsystems. During development special attention should be paid to the appropriate human-machine interface with consideration to the traveller's disabilities. The most important novelties of this CogInfoCom application: value-added, location-based, door-to-door and personalized information services with decision support using real-time and predicted data.

An advanced route planner or rather mobilitiy manager application ideally is a self-learning, adaptive applicaton which uses artifical intelligence or other cognitive methods. From the travellers' trajectory, behaviour, experiences, user profile, personalization, traffic conditions, infrastructure status, etc. the application determines the best (optimum) route or mobility chain for the user. Crowd-sourcing techniques and cognition of the properties of the infrastructure have more and more importance in this regard [22]. This 'ideal' CogInfoCom application continuously re-examine and re-calculate the best route according to the current input data using entirely adaptive and self-learning methods during the calculation

Distribution of information management processes between the component types is summarized in Fig 2. All three levels are/can be self-learning. Traveller itself is also an important information source either directly or indirectly. Travellers observe each other's behaviour and movement and as a concequence react. These observations contribute to the cognitive process of the human components. The humanmachine background system also 'observes' the travellers (e.g. tracking). From these observations the machine system can draw conclusions realizing in this way the cognitive process. In this 'distributed intelligence' structure the cognitive capabilities and decision levels are to be assigned to travellers, travellers with the terminals, or travellers with the entire ICT system. From users' perspective the borders between machine and human components are blurred within the 'background' system. The travellers (as purely human components) have varied levels of cognitive capabilities. These differences can be moderated by the capabilities of the machine components. In this way augmented cognition can be realized.

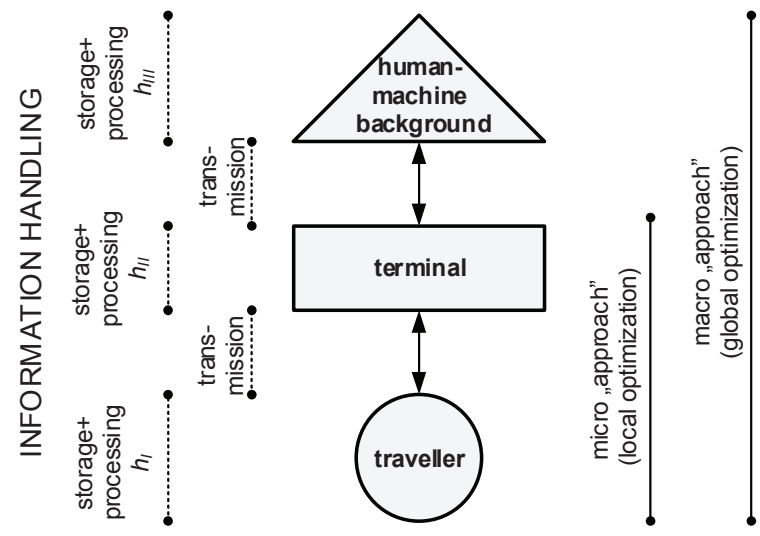

Fig. 2. Distribution of information management processes between the component types

The cognitive processes can be interpreted as producing value-added information services from raw data (applying 
data fusion techniques). This value chain consists of several steps and being result of cooperation of different actors (e.g. content provider, service provider) [22]. Realization of the cognitive process in the machine subsystems needs a plenty of up-to-date background information from the sensors (e.g. user, infrastructure, vehicles, weather, commerce) and efficient processing method.

The travellers' information management processes are modelled in Fig. 3. They perceive the needed information with the sens-organs (hearing and mostly eyesight). The information arrives from

- traveller information system,

- the other participant (travellers, drivers) and

- $\quad$ own experiences, knowledge.

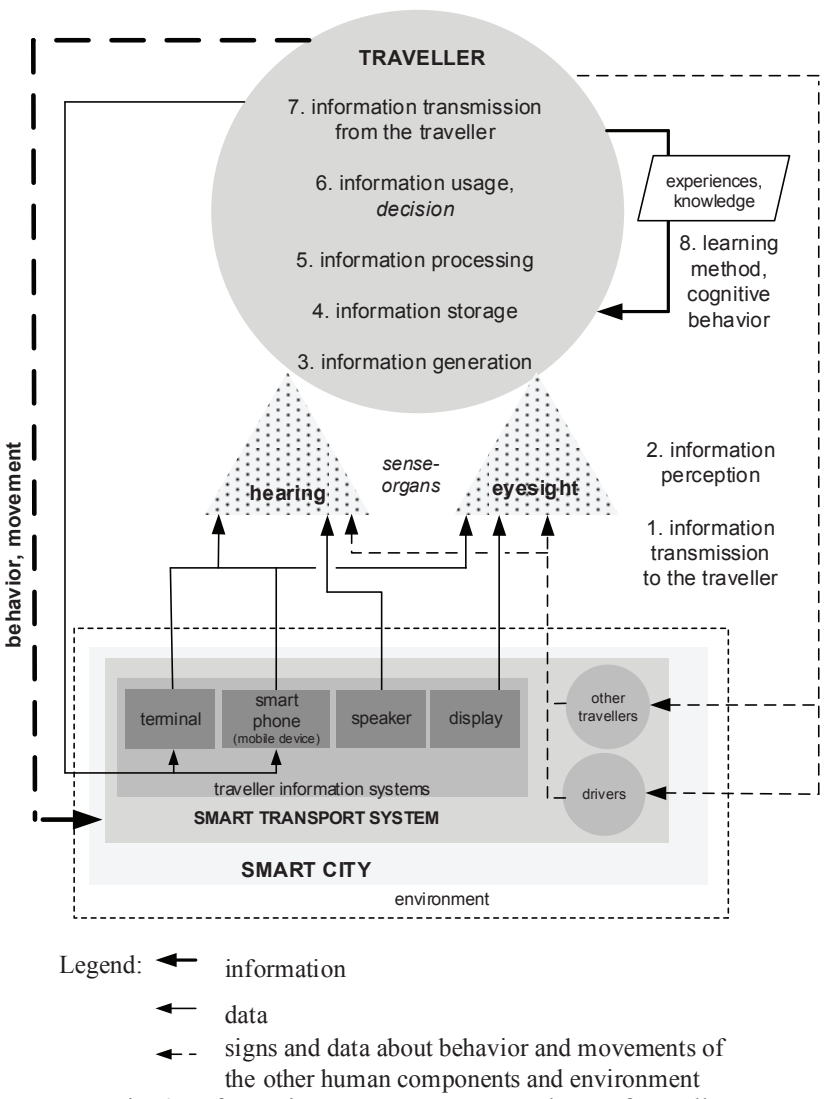

Fig. 3. Information management procedures of travellers

Between humans and ICT tools three levels of interaction can be observed. The first level means direct relationship and allows direct sensing and control. In the senond level the communication and interaction occur through human sensory modalities. In the third level the application examine the users' collective behaviour [23]. In the case of travellers both the second and the third levels are/should be realized.

The information is provided by either individual or collective devices. The effects may vary as: guidance, influence, prohibition, decision support or warning. There are interrelations between information provided and sensory modes, as well as the role of the information (substitutive or augmentative) and its effects. The collective (up-to-date) traffic information is provided by displays or speakers in the public transportation stops or intermodal traffic centres. Information generation in human minds requires capabilities, acquired skills (e.g. reading). Information storage and processing are results of encephalic (central nervous) activity. Passengers make decisions on the basis of "accepted" and interpreted information; meanwhile the individual nature (e.g. emotional state, tiredness, etc.) or personal attitudes (e.g. education, environment-consciousness) are also dominant. Within human body, nerves mediate the "control" signs among the certain organs. All of these actions are resulted in passenger behaviour and movements. Passenger-flows are formed from these moving persons. One part of movements is made as routine, while other part is the result of long preliminary deliberation. Each travel experience is an impulse for the next travel planning procedure. The acquired experiences and knowledge is the basis of the cognitive behaviour.

In general two modes of communication are distinguished [1]:

- $\quad$ intra-cognitive communication (e.g. driver informs passengers),

- $\quad$ inter-cognitive communication (e.g. ticket purchase from automatic device).

In passenger transportation an intermediate type may also be introduced, when the information transfer occurs between two humans with slightly different cognitive capabilities, namely one of them is supported by artificially cognitive system (e.g. dispatcher with ICT tools and value-added information informs passengers without this 'background').

The type of communication between the ICT terminal and the traveller is sensor-bridging communication, where vision, audition and vibrotactile types are realized. In case of information provision the aim is increasing the user experience through a kind of 'entertainment'. In case of information acquireing the aim is minimization of number of actions required from travellers (passive methods - e.g. be-in be-out fare collection techniques). The used representations: alphanumeric characters, pictures (with animation), films, sounds/voices, intensity of vibration. Both representationsharing and representation-bridging communications are applied.

\section{CONCLUSIONS}

The development/evolvement of the presented CogInfoCom (smart transportation) system consists of several steps requiring long time. Results summarized here are the first step of this process. The main contributions of the paper was modelling smart traveller focusing on the cognitive capabilities and processes and insertion smart traveller into wider frameworks (smart transportation, smart city). The key finding was making researches regarding the cognitive 
behaviour and decision-making. We faced (as lessons learnt) that application of scope and goals of CogInfoCom in transportation requires wide knowledge and adequate level of abstraction. It causes also difficulties that new functions fade in and the existing ones evolve day by day, therefore flexible models had to be devised. As well as beside the adaptive (automatic) information management processes the human factor is still necessary in many cases.

Our future research focuses on the further analysis (based on questionnaires) of behaviour and decision-making of travellers considering the scope of CogInfoCom and the elaboration of the smart traveller's application.

The achieved results give theoretical principles for planning and implementation of this complex infocommunication system revealing the imperfections of existing processes. In this way the utilization of the available and new data can be improved.

\section{REFERENCES}

[1] Baranyi, P., Csapó, Á. "Definition and Synergies of Cognitive Infocommunications." Acta Polytechnica Hungarica, 9 (1), pp. 67-83. ISSN $1785-8860$

[2] Přibyl, O. "Transportation, intelligent or smart? On the usage of entropy as an objective function". Smart Cities Symposium, 24-25 June 2015. Prague, Czech Republic, pp. 1-5 DOI: $10.1109 /$ SCSP.2015.7181564, ISBN: 978-1-4673-6727-1

[3] Nagy, E., Csiszár, Cs., "Research on Automation of Operative Scheduling in Urban Public Transportation," Acta Technica Jaurinensis 'Series Transitus'. Vol.6. No. 3. pp. 94-109. Györ, 2013. http://acta.sze.hu/index.php/acta/article/view/229

[4] Prileszky, I., Horváth, B., "New Ways in Vehicle and Crew Scheduling," Acta Technica Jaurinensis 'Series Transitus'. Vol.4. No. 2. pp. 297-304. Györ, 2011.

http://acta.sze.hu/index.php/acta/article/view/151

[5] Soltész, T., Kózel M., Csiszár Cs., Centgráf T., Benyó B.: "Information System for Road Infrastructure Booking," Periodica Polytechnica Transportation Engineering. Vol.39. No. 2. pp. 55-62. Budapest, 2011. DOI: 10.3311/pp.tr.2011-2.02 http://www.pp.bme.hu/tr/article/view/1825

[6] Sándor, Zs., Csiszár, Cs., "Development Stages of Intelligent Parking Information Systems for Trucks," Acta Polytechnica Hungarica. 10:(4) pp. 161-174. Paper 42. (2013) DOI: 10.12700/APH.10.04.2013.4.10

http://www.uni-obuda.hu/journal/Sandor_Csiszar_42.pdf

[7] Sándor, Zs., Csiszár, Cs., "Role of Integrated Parking Information System in Traffic Management," Periodica Polytechnica Civil Engineering. Vol.59. No. 4. pp. Budapest, 2015. DOI: 10.3311/PPci.7361 http://www.pp.bme.hu/ci/article/view/7361

[8] Esztergár-Kiss, D., Csiszár, Cs., "Evaluation of Multimodal Journey Planners and Definition of Service Levels," International Journal of Intelligent Transportation Systems Research. 2014 DOI 10.1007/s13177-014-0093-0 http://link.springer.com/article/10.1007\%2Fs13177-014-0093-0

[9] Csiszár, Cs., Tóth, J., "BusEye online személyre szabott utastájékoztató mobil alkalmazás fejlesztése," (BusEye - Development of Online Personalized Passenger Information Mobile Application) Közlekedéstudományi Konferencia, Györ, 2014. március 27-28. Konferencia kiadvány 57-70. o. (ISBN 978-615-5298-30-1). *
[10] Földes, D., Csiszár, Cs., "Route Plan Evaluation Method for Personalized Passenger Information Service," Transport Journal 2015 Volume 30 (3): 273-285 (Special Issue on Smart and Sustainable Transport) DOI: 10.3846/16484142.2015.1086889

[11] Varga, N.; Bokor, L.; Fischer, H-J. "LDM-based dynamic network discovery and selection for IPv6 mobility management optimization in C-ITS environments", "4th International Conference on Models and Technologies for Intelligent Transportation Systems (MT-ITS 2015)", 3-5 June 2015, Budapest, Hungary, pp. 483-490. DOI:10.1109/MTITS.2015.7223298

[12] Kramers, A., "Designing Next Generation Multimodal Traveler Information Systems to Support Sustainability-oriented Decisions," Environmental Modelling \& Software, Thematic issue on Modelling and evaluating the sustainability of smart solutions 56, pp. 83-93. 2014. DOI:10.1016/j.envsoft.2014.01.017

[13] Jou, R.-C.; Lam, S.-H.; Liu, Y.-H.; Chen, K.-H. 2005. Route switching behavior on freeways with the provision of different types of real-time traffic information, Transportation Research Part A: Policy and Practice 39, 445-461. doi:10.1016/j.tra.2005.02.004

[14] Yue, Y., Lan, T., Yeh, A.G.O., Li, Q.-Q., "Zooming into Individuals to Understand the Collective: A review of Trajectory-based Travel Behaviour Studies," Travel Behaviour and Society. 1, pp. 69-78. 2014. DOI:10.1016/j.tbs.2013.12.002

[15] Bekhor, S.; Cohen, Y.; Solomon, C. 2013. Evaluating long-distance travel patterns in Israel by tracking cellular phone positions, Journal of Advanced Transportation 47, 435-446. doi:10.1002/atr.170

[16] Szabo, R.; Farkas, K.; Wiandt, B. 2013. Measurements of a real-time transit feed service architecture for mobile participatory sensing, in: Wireless Days (WD), 2013 IFIP. Presented at the Wireless Days (WD), 2013 IFIP, pp. 1-4. doi:10.1109/WD.2013.6686542

[17] Steenbruggen, J., Tranos, E., Nijkamp, P., "Data from Mobile Phone Operators: A Tool for Smarter Cities?" Telecommunications Policy, New empirical approaches to telecommunications economics: Opportunities and challenges Mobile phone data and geographic modelling. 39, 335-346. 2015. DOI:10.1016/j.telpol.2014.04.001

[18] Kusakabe, T., Asakura, Y., "Behavioural Data Mining of Transit Smart Card Data: A Data Fusion Approach," Transportation Research Part C: Emerging Technologies. 46, pp. 179-191. 2014. DOI:10.1016/j.trc.2014.05.012

[19] Csiszár, Cs., "Model of Integrated Intelligent Passenger Information Systems," Periodica Polytechnica Transportation Engineering. Vol.31. No. 1-2. pp. 17-44. Budapest, 2003. DOI: 10.3311/pp.tr.20031-2.02, http://www.pp.bme.hu/tr/article/view/1935

[20] Csiszár, Cs.; Földes, D. "Analysis and Modelling Methods of Urban Integrated Information System of Transportation". Smart Cities Symposium, 24-25 June 2015. Prague, Czech Republic, pp. 1-10 DOI:10.1109/SCSP.2015.7181574, ISBN: 978-1-4673-6727-1

[21] Csiszár, Cs., "Személyközlekedési módok összekapcsolása informatikai eszközökkel - tudatos közlekedés," (Interconnection of Passenger Transportation Modes by Infocommunication - Conscious Transport) Közlekedéstudományi Konferencia, Győr, 2012.03.29-30. Konferencia kiadvány 341-350. o. (ISBN 978-963-9819-84-9). *

[22] Szabo, R.; Farkas, K.; Ispany, M; Benczur, A.A.; Batfai N.; Jeszenszky, P.; Laki, S.; Vagner, A.; Kollar, L.; Sidlo, C. "Framework for smart city applications based on participatory sensing," in 4th IEEE International Conference on Cognitive Infocommunications, 2013, pp. 295-300. DOI: 10.1109/CogInfoCom.2013.6719260

[23] Baranyi, P.; Csapó, Á, Várlaki, P. “An Overview of Research Trends in CogInfoCom." 18th International Conference on Intelligent Engineering Systems - INES 2014. IEEE Hungary Section, Tihany, pp. 181-186 DOI:10.1109/INES.2014.6909365

* in Hungarian 